\title{
Implementasi Model Waterfall pada Pengembangan Sistem Informasi Monitoring Prestasi Mahasiswa
}

\author{
Implementation of Waterfall Model in the Development of Student \\ Achievement Monitoring Information Systems
}

\author{
Devi Rahmawati ${ }^{1}$, Annas Setiawan Prabowo ${ }^{2}$, Riyadi Purwanto ${ }^{3}$ \\ 1,2,3 Program Studi Teknik Informatika, Politeknik Negeri Cilacap \\ e-mail: devirahmawati071@gmail.com ${ }^{1}$, annassetiawanp@pnc.ac.id², adidokbayu85@gmail.com³
}

\begin{abstract}
Abstrak
Politeknik Negeri Cilacap (PNC) merupakan Politeknik yang memiliki beberapa beasiswa di dalamnya. Bidikmisi merupakan salah satu beasiswa yang terdapat pada PNC. Penerima beasiswa bidikmisi diharuskan melaporkan prestasi setiap semester ke pihak Biro Administrasi Akademik dan Kemahasiswaan (BAAK) masih sering mengalami masalah, diantaranya yaitu keterlambatan mahasiswa dalam mengumpulkan laporan hasil prestasi, pihak BAAK merasa kesulitan dalam memantau perkembangan prestasi mahasiswa khususnya dibidang nonakademik karena semua datanya ada di masing-masing mahasiswa. Penelitian ini berfokus pada pemantauan terkait prestasi mahasiswa. Pembuatan sistem ini menggunakan metode waterfall karena sistematis. Hasil kuesioner menunjukan sistem ini dapat membantu dalam proses pengelolaan dan pemantauan prestasi mahasiswa dengan presentase yang didapat sekitar $60 \%$ menyatakan baik dan dapat membantu mahasiswa untuk meberitahukan hasil pencapaian prestasi yang dimilikinya dan dapat diakses kapan saja tanpa harus menunggu informasi maupun mendatangi ruangan BAAK dengan presentase yang didapat dari hasil kuesioner sekitar $70 \%$ menyatakan baik.
\end{abstract}

Kata Kunci: Sistem Informasi Monitoring, Prestasi, Metode Waterfal.

\begin{abstract}
Cilacap State Polytechnic (PNC) is a Polytechnic that has several scholarships in it. Bidikmisi is one of the scholarships available at PNC. Bidikmisi scholarship recipients are required to report their achievements every semester to the Biro Administrasi Akademik dan Kemahasiswaan (BAAK) which still often experiences problems, including student delays in collecting achievement reports, BAAK finds it difficult to monitor the progress of student achievement, especially in the non-academic field because all the data is in each student. This research focuses on monitoring related to student achievement. Making this system using the waterfall method because it is systematic. The results of the questionnaire show that this system can assist in the process of managing and monitoring student achievement with a percentage of around 60\% stating it is good and can help students to notify the results of their achievements and can be accessed at any time without having to wait for information or visit the BAAK room with a high percentage. obtained from the results of the questionnaire about $70 \%$ stated good.
\end{abstract}

Keywords: Monitoring Information System, Achievement, Waterfal Method.

\section{Pendahuluan}

Perkembangan Teknologi Informasi yang semakin hari semakin mengalami peningkatan yang pesat menimbulkan kemudahan-kemudahan dan berdampak pada aktifitas manusia secara langsung, menjadikan manusia mampu mengolah data dan menyajikan informasi yang berkualitas, lebih efektif dan efisien. Sistem informasi merupakan komponen penting dalam teknologi penyampaian informasi yang dibutuhkan pada suatu institusi. Banyak sekali peran penting teknologi informasi dimasa sekarang, salah satunya adalah di bidang pendidikan, contohnya yaitu dalam membangun sistem informasi monitoring prestasi akademik maupun non akademik mahasiswa sebagai upaya untuk membantu aktivitas pengelolaan data prestasi mahasiswa.

Polieknik Negeri Cilacap adalah salah satu politeknik negeri yang ada di Jawa Tengah, didirikan pada tahun 2008 dan memiliki tujuh program studi. Pada masing-masing program studi terdapat beberapa aktivitas akademik atau perkuliahan maupun diluar perkuliahan atau nonakademik (Organisasi, UKM, PMW, dll) yang terkadang tidak jarang mahasiswa memperoleh sebuah pencapaian atau prestasi tertentu 
baik individu ataupun kelompok. Hal ini bisa berdampak baik pada akreditasi kampus, selain itu dapat menarik minat dari perusahaan atau lembaga untuk menawarkan beasiswa atau menawarkan lapangan pekerjaan setelah lulus kuliah.

Di Politeknik Negeri Cilacap proses pemantauan dan pengelolaan data-data prestasi mahasiswa untuk setiap jurusan belum dilakukan secara online dan terkomputerisasi, salah satunya dibidang nonakademik ketika mahasiswa mengikuti sebuah kegiatan perlombaan atau aktivitas lain diluar perkuliahan lalu mendapatkan penghargaan atau kejuaraan, tidak ada sistem yang mendata dan mengelola hal tersebut sehingga Bidang Akademik Kemahasiswaan terkadang merasa kesulitan ketika mencari data prestasi mahasiswa karena data yang berupa sertifikat atau piagam disimpan sendiri oleh mahasiswa terutama bagi mahasiswa yang mendapatkan beasiswa bidikmisi, kebutuhan akan hal tersebut biasanya di akhir semester bagian kemahasiswaan membuat pengumuman agar mahasiswa bidikmisi mengumpulkan berkas laporan perkembangan akademik dan nonakademik yang dimilikinya, namun terkadang membutuhkan proses yang lama karena keterlambatan mahasiswa mengumpulkan langsung ke BAAK, Selain itu proses pemberitahuan untuk pembinaan mahasiswa bidikmisi yang mempunyai ipk rendah juga belum dilakukan notifikasi secara online melalui email sehingga harus diberitahukan secara langsung.

Berdasarkan hal tersebut, penulis melakukan penelitian dengan judul: "Penerapan Model Waterfall Pada Perancangan Sistem Informasi Monitoring Prestasi Mahasiswa" yang diharapkan dapat membantu dan mempermudah dalam mengatasi masalah yang saat ini sedang berjalan dan menjadi sistem informasi yang bermanfaat bagi pengguna.

Adapun penelitian sebelumnya yang relevan, diantaranya penelitian yang bertujuan untuk menghasilkan sistem informasi lapor prestasi mahasiswa, menjadi terobosan baru dalam berinteraksi dengan mahasiswa, aliran informasi menjadi lebih interaktif dan transparan menggunakan metoe RAD [1], selain itu ini dibangun sistem dengan tujuan untuk merancang sebuah sistem informasi monitoring akademik dan prestasi siswa dengan perancangan metode waterfall yang dapat membantu dan memudahkan pihak sekolah dan wali murid dalam memonitoring kegiatan akademik dan prestasi siswa [2], lalu perancangan monitoring prestasi akademik dan aktifitas siswa menggunakan pendekatan key performance indicator yang memudahkan pengguna melakukan pengawasan terhadap nilai atau prestasi siswa dan mempermudah menyimpan data-data jika terjadi sesuatu yang tidak diinginkan oleh sekolah [3].

Adapun teori dan literatur yang berkaitan dengan penelitian jurnal penulis sebagai berikut:

\section{Sistem Informasi}

Sistem merupakan sekumpulan orang yang saling bekerja sama yang di dalamya terdapat aturan yang terstruktur untuk membentuk satu kesatuan yang melaksanakan suatu fungsi tertentu dalam mencapai tujuan. Sedangkan informasi merupakan kumpulan data yang kemudian diolah menjadi lebih berarti bagi yang menerimanya, serta berfungi untuk meminimalisir ketidakpastian dan kesalahan dalam proses pengambilan keputusan mengenai suatu keadaan. Jadi, Sistem informasi adalah gabungan yang terorganisasi dari manusia, perangkat lunak, perangkat keras, jaringan komunikasi dan sumber data dalam mengumpulkan, mengubah, dan menyebarkan informasi dalam organisasi[4].

\section{Sistem Informasi Monitoring}

Sistem Informasi monitoring merupakan suatu proses pengumpulan data dari berbagai sumber daya. Data yang dikumpulkan adalah data secara realtime. Tahapan dalam sebuah sistem monitoring secara garis besar yaitu terdiri dari pengumpulan data, analisis data, menampilkan data. Langkah-langkah yang dikerjakan pada suatu sistem monitoring yaitu diawali dari pengumpulan data seperti data dari hardware information, network traffic dan lain-lain yang kemudian data tersebut dianalisis dan terakhir data tersebut akan ditampilkan[5].

\section{Prestasi Akademik dan Nonakademik}

Prestasi akademik adalah faktor yang menjai tolak ukur dalam keberhasilan seseorang dalam belajar yang mencakup keseluruhan hasil yang telah dicapai yang diperoleh melalui tahapan atau proses belajar akademik (academic achievement). Dari pernyataan tersebut dapat disimpulkan bahwa prestasi akademik adalah hasil dari kegiatan belajar untuk mendalami sejauh mana seseorang menguasai bahan pelajaran yang diajarkan. Keberhasilan belajar bisa dinilai dengan menggunakan prestasi akademiknya. Ada dua macam pencapian belajar seorang mahasiswa, yaitu IPK yang menunjukkan prestasi akademis dan keuntungan ekonomis serta kualitas hidup ketika selesai perkuliahan[6].

Prestasi nonakademik adalah prestasi yang tidak ada kaitannya dengan kegiatan akademis yang identik dengan proses belajar-mengajar diantaranya membaca, menulis dan berhitung, yang bisa diperoleh 
dengan mengasah kemampuan di lembaga formal seperti di sekolah atau kampus. Prestasi ini bisa didapat melalui berkegiatan, berorgansisasi, dan juga bersosialisasi dengan orang lain. Prestasi ini didapat biasanya melalui kegiatan kemahasiswaan yang diadakan di kampus atau komunitas yang ada di lingkungan kediamannya.

\section{Rekayasa Web}

Rekayasa web merupakan suatu aplikasi yang didalamnya dilakukan pendekatan sistematis, disiplin dan terukur untuk pengembangan, operasi dan pemeliharaan aplikasi berbasis web (Web-bassed application). Litratur terkait rekayasa web biasanya mengacu pada situs, aplikasi dan sistem berbasis berbasis web.

Adanya rekayasa web ini menunjukan terdapat kebutuhan yang difokuskan pada kesuksesan pengembang aplikasi dan sistem berbasis web. Rekayasa web menerapkan sains, rekayasa dan pendekatan secara sistematis serta prinsip-prinsip manajemen untuk keberhasilan terhadap pengembangan, penyebaran, pemeliharaan aplikasi dan sistem web yang berkualitas tinggi. Rekayasa web mempermudah para pengembang system yang berada di bawah control, memperkecil berbagai risiko yang akan terjadi serta meningkatkan kualitas, dapat dipelihara dan mempunyai skalabilitas aplikasi web. Tujuan utama dari rekayasa web adalah keberhasilan dalam mengatur kompleksitas dan keanekaragaman pengembangan aplikasi web[7].

\section{Rekayasa Perangkat Lunak}

Perangkat lunak (Software engineering) merupakan suatu program komputer yang terhubung dengan dokumentasi perangkat lunak seperti kebutuhan, model sistem dan cara penggunaannya. Rekayasa perangkat lunak adalah perancangan sebuah perangkat lunak yang mempunyai tujuan unntuk membangun sebuah perangkat lunak bernilai ekonomis dan juga bekerja secara efisien dengan menggunakan mesin. Proses perangkat lunak juga meliputi teknologi yang mempopulasikan metode-metode (method) teknis, alat-alat bantu(tools) otomastis dan prosedur-prosedur (procedure) atau sering disebut dengan proses[8].

\section{Pemrograman Berorientasi Objek}

Metodologi berorientasi objek adalah suatu langkah pembangunan perangkat lunak sebagai kumpulan objek yang beri data dan diberlakukan suatu operasi didalamnya. Metodologi berorientasi objek merupakan cara dalam membangun sistem perangkat lunak melalui pendekatan objek secara sistematis. Salah satu tahapan kegiatan dalam metode berorientasi objek yaitu pemrograman berorientasi objek[9].

Pemrograman berorientasi objek merupakan suatu strategi atau cara baru untuk membuat program atau merancang sistem dengan memperhatikan objek. Metode berorientasi objek ini dipilih sebagai solusi karena banyaknya maslah yang timbul pada metode lama seperti pada saat mentransformasikan hasil pengembangan yang menimbulkan kesulitan untuk ke tahap selanjutnya, contohnya pada metode pendekatan terstruktur, aplikasi yang ada di masa lalu mempunyai jenis yang berbeda dengan aplikasi yang dikembangkan pada saat ini. Beberapa konsep dasar metodologi berorientasi objek: Kelas (clas), Objek(object), Metode (method), Atribut (attribute), Abstrak (abstraction), Enkapsulasi (encapsulation), Pewarisan (inheritance), Polimorfise (polymorphism) dll[10].

\section{Basis Data}

Basis data adalah kumpulan data yang saling berelasi. Data sendiri merupakan fakta mengenai objek orang dan lain - lain. Data dinyatakan dengan nilai(angka, deretan karakter atau simbol)[11].

\section{Metode Penelitian}

Metode penelitian dalam penelitian ini yaitu menggunakan metode deskriptif. Metode deskriptif merupakan prosedur pemecahan masalah yang diteliti dengan cara mendeskripsikan suatu keadaan subjek atau objek dalam penelitian yang diantaranya dapat berupa individu, lembaga, masyarakat atau yang lainnya pada saat sekarang berdasarkan fakta yang apa adanya. Tahapan dalam metode ini diantaranya :

\section{Tahap Pengumpulan Data}

Tahap pengumpulan data bisa didapat secara langsung dari objek penelitian. Tahapan tersebut diantaranya:

a. Studi Pustaka

Studi kepustakaan merupakan aktivitas untuk mengumpulkan informasi yang relevan dengan topik permasalahan yang menjadi obyek penelitian. Studi penelitian dilakukan dengan cara mempelajari, meneliti, serta menelaah berbagai literature atau rujukan dari perpustakaan yang 
bersumber dari buku-buku, jurnal ilmiah atau situs-situs di internet yang berkaitan dengan topik penelitian.

b. Studi Lapangan

Studi lapangan yaitu kegiatan dengan berkunjung ke tempat yang akan diteliti secara langsung untuk dilakukan pengumpulan data. Terdiri dari:

1) Wawancara

Wawancara merupakan teknik pengumpulan data dengan melakukan tanya jawab dengan staff bagian bidang akademik dan kemahasiswaan yang ada di Poiteknik Negeri Cilacap.

2) Observasi

Observasi merupakan teknik pengumpulan data dengan cara melakukan pengamatan secara langsung pada tempat yang akan diteliti, dalam hal ini yaitu Politeknik Negeri Cilacap.

\section{Tahap Pengembangan Sistem}

Tahap pengembangan sistem yang dilakukan dalam pembagunan Sistem Informasi Monitring Prestasi Mahasisa Berbasis Web ini menggunakan metode Waterfall. Menurut Ian Sommerville, Terdapat lima tahapan dari metode Waterfall[12].

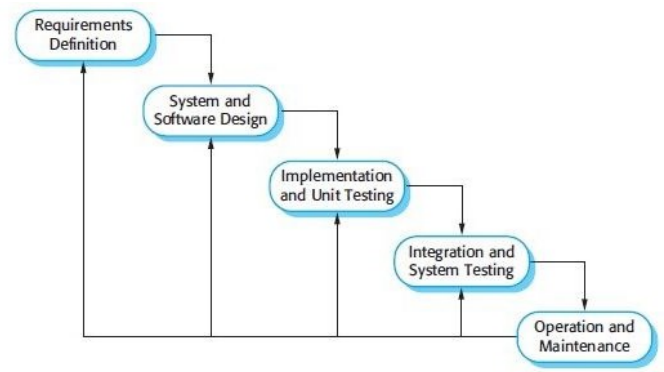

Gambar 1. Tahap Pengembangan Sistem Informasi Monitoring Prestasi Mahasiswa

\section{a. Requirements}

Merupakan tahapan penetapan fitur, melakukan konsultasi dengan pengguna sistem untuk mengetahui kendala dan tujuan sistem, kemudian akan ditetapkan dengan rinci dan digunakan untuk spesisfikasi sistem.

b. System and Software Design

Pada tahap ini merupakan tahap dibentuknya suatu arsitektur sistem berdasarkan syarat-syarat yang telah ditetapkan. Selain itu juga, dilakukan suatu identifikasi dan penggambaran mengenai abstraksi dasar sistem perangkat lunak berserta hubungannya.

c. Implementation and Unit Testing

Tahapan ini merupakan tahap diterapkannya hasil dari desain perangkat lunak yang dijadikan sebagai suatu program. Lalu setiap unit akan diuji untuk ditentukan apakah spesifikasinya sudah terpenuhi.

\section{d. Integration and System Testing}

Dalam tahap ini, akan saling diintegrasikannya setiap unit program dan diuji sebagai satu sistem yang utuh untuk memastikan sistem sudah memenuhi persyaratan yang ada.

Pengujian sistem ini menggunakan model pengujian black box. Pengujian black box memungkinkan perekayasa perangkat lunak mendapatkan serangkaian kondisi input yang sepenuhnya menggunakan semua persyaratan fungsional untuk suatu program. Terdapat beberapa teknik dalam pengujian black box diantaranya:

1) Equivalence Partition merupakan sebuah pengujian berdasarkan masukkan data pada setiap form sistem, setiap menu masukkan akan dilakukan pengujian[13]. Metode Equivalence Partition dilakukan dalam tujuh tahap yaitu: menentukan use case yang akan diuji, menentukan kriteria, mendefinisikan partisi, membuat data uji, membuat kasus uji, melakukan pengujian, dan mengevaluasi hasilnya[14].

2) Boundary Value Analysis merupakan teknik pengujian perangkat lunak di mana tes dirancang untuk mencakup perwakilan dari nilai batas dalam kisaran, digunakan untuk menentukan nilai batas bawah dan batas atas dari data yang ingin diuji dengan menguji nilai batas bawah dan batas atas[15]. Metode Boundary Value Analysis memiliki sembilan tahap diantaranya: menentukan use case yang akan diuji, menentukan kriteria, menentukan nilai batas, menentukan nilai bawah batas 
dan nilai atas batas, membuat data uji, membuat kasus uji, melakukan tes, dan mengevaluasi hasil[14].

e. Operation and Maintenance

Dalam tahap ini, sistem mulai di-instal dan dipergunakan. Lalu, akan diperbaiki jika ada error yang tidak ditemukan pada saat tahap pembuatan. Selain itu juga dilakukan penambahan fitur dan fungsi baru dalam pengembangan sistem.

\section{Hasil dan Pembahasan \\ Hasil Penelitian}

Dalam penelitian ini ada beberapa tahapan yang dilakukan. Tahapan yang pertama kali dilakukan yaitu pengumpulan data, seperti melakukan studi pustaka dengan mempelajari, meneliti dan menelaah buku-buku penelitian sebelumnya yang berkaitan dengan pengembangan sistem, kemudian studi lapangan yaitu dengan melakukan observasi dan wawancara dengan pihak BAAK Politeknik Negeri Cilacap yang terkait dengan penelitian.

Tahapan yang kedua yaitu tahap pengembangan sistem. Tahapan pengembangan sistem antara lain:

1) Analisis Kebutuhan Sistem

2) Desain Sistem

3) Pengkodean

4) Pengujian

5) Penerapan Program dan Pemeliharaan

Dari penelitian ini dihasilkan Penerapan Metode Waterfall Pada Perancangan Sistem Informasi Monitoring Prestasi Mahasiswa. Sistem tersebut digunakan untuk mengelola dan memantau data prestasi mahasiswa secara akademik maupun nonakademik yang mencakup proses penyimpanan data nonakademik, proses penyampaian grafik nilai akademik mahasiswa, proses penyampaian informasi perangkingan mahasiswa, dan proses pelaporan perkembangan pestasi oleh BAAK.

\section{Tampilan Antarmuka}

a. Halaman Registrasi Mahasiswa

Pada halaman registrasi terdapat text input yang terdiri dari nim, nama mahasiswa, username dan password serta terdapat tombol register untuk mendaftarkan akun agar mahasiswa dapat melakukan login. Selain itu, dibawah tombol register terdapat link untuk menuju ke halaman login dan halaman lupa password.

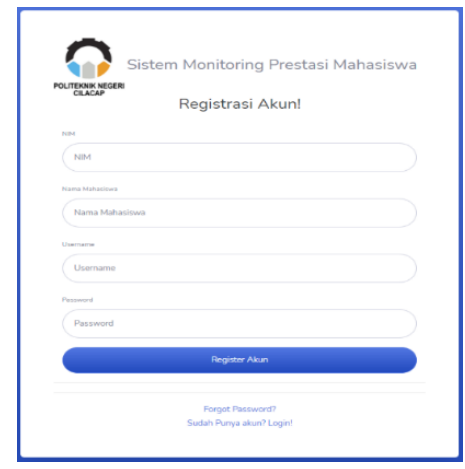

Gambar 2. Halaman Registrasi Akun Mahasiswa

b. Halaman Simpan Data Mahasiswa

Halaman tambah data mahasiswa terdapat form inputan untuk menambah data mahasiswa. Pada halaman ini Mahasiswa dapat memasukan NIM, Nama, Kelas, Tempat Lahir, Tanggal Lahir, Tahun Masuk, Beasiswa, Email, Status dan Foto. Dengan menekan tombol ubah, maka data yang dimasukan tersimpan. 


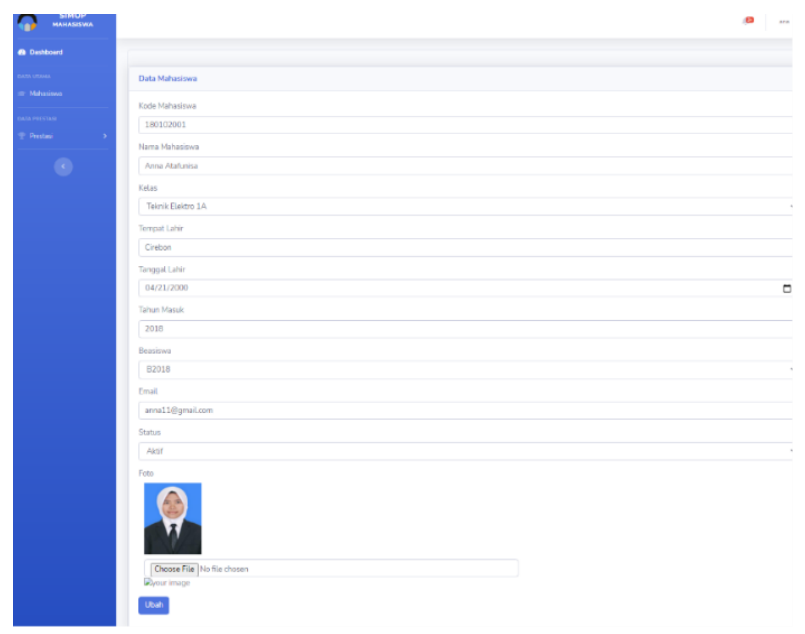

Gambar 3. Halaman Simpan Data Mahasiswa

c. Halaman Simpan Data Prestasi Nonakademik

Halaman tambah data nonakademik terdapat form inputan untuk menambah data nonakademik.

Pada halaman ini Mahasiswa dapat memasukan NIM, Nama, Kegiatan, Tingkat, Waktu Pelaksanaan, Hasil, dan Bukti Prestasi. Dengan menekan tombol simpan, maka data yang dimasukkan tersimpan.

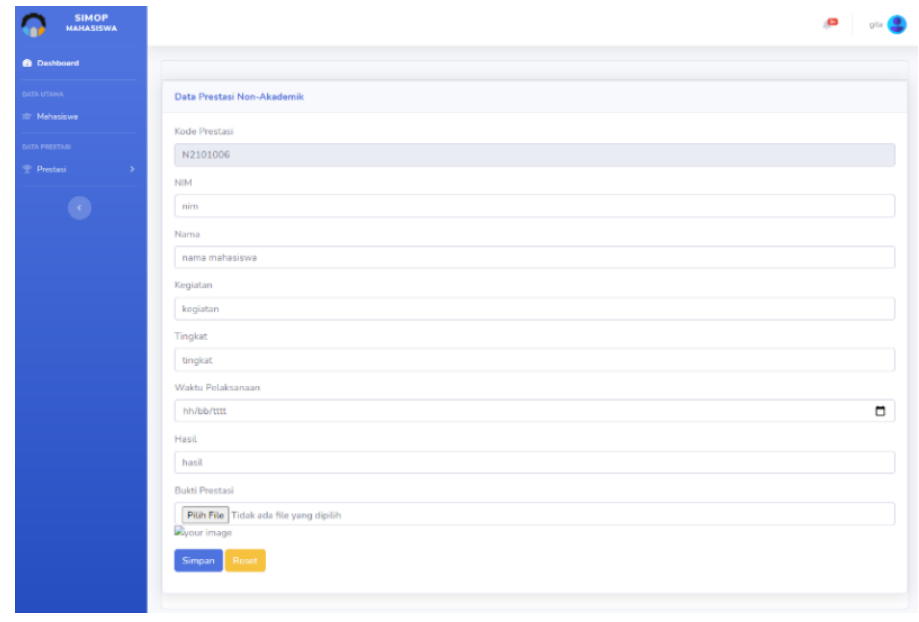

Gambar 4. Halaman Simpan Data Non-akademik

d. Halaman Lihat Data Mahasiswa

Halaman melihat data mahasiswa ini menampilkan data gridview yang berisi No, Foto, Kode(NIM), Nama Mahasiswa, Kode Kelas, Tempat Lahir, Tanggal Lahir, Tahun Masuk, Kode Beasiswa, Email dan Status. Didalam data gridview, setiap data yang ada memiliki tombol Aksi yang terdiri dari tombol edit yang berfungsi untuk mengubah data mahasiswa dan tombol hapus yang digunakan untuk menghapus data mahasiswa terpilih. 


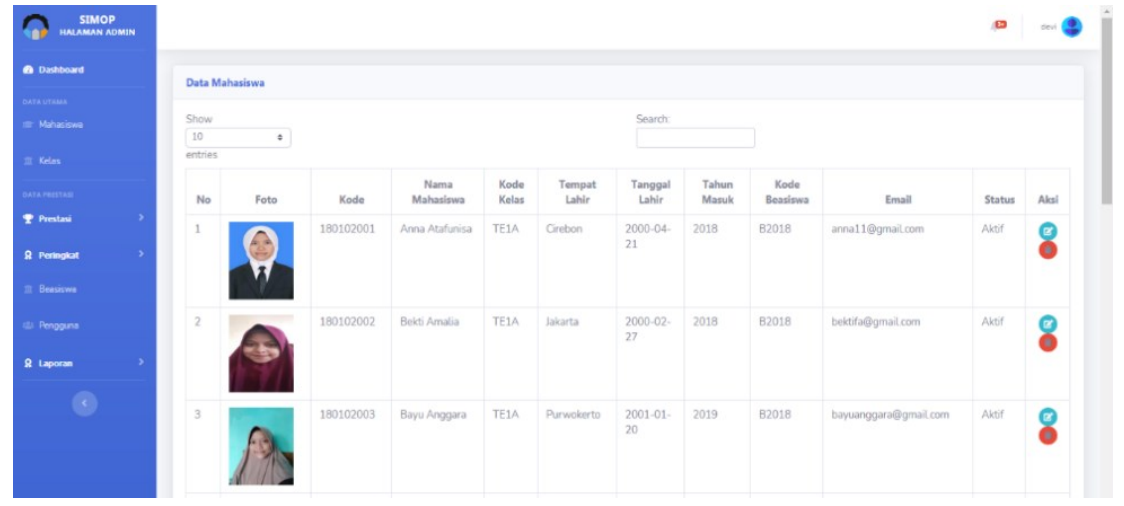

Gambar 5. Halaman Lihat Data Mahasiswa

e. Halaman Lihat Data Prestasi Nonakademik

Halaman melihat data nonakademik pada admin ini menampilkan data gridview yang berisi No, Kode Prestasi, Nim, Nama Mahasiswa, Kegiatan, Tingkat, Waktu Pelaksanaan, Hasil dan Bukti Prestasi. Didalam data gridview, setiap data yang ada memiliki tombol Aksi yang terdiri dari tombol hapus yang berfungsi untuk menghapus data nonakademik dan tombol open folder yang digunakan untuk melihat detail nonakademik terpilih.

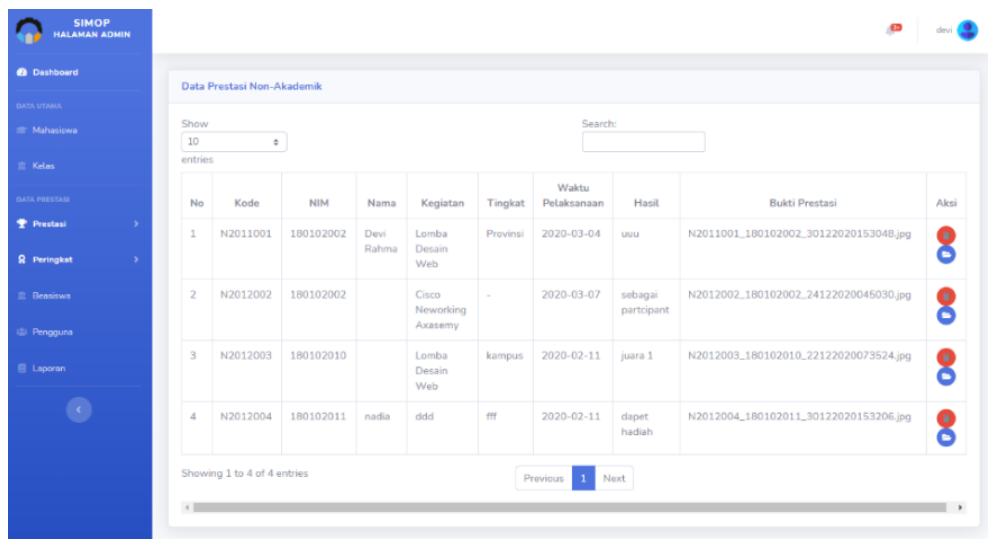

Gambar 6. Halaman Lihat Data Prestasi Non-akademik

f. Halaman Lihat Detail Prestasi Nonakademik

Halaman melihat detail nonakademik pada Anggota BAAK ini menampilkan data prestasi nonakademik yang berisi Kode Prestasi nonakademik, Nim, Nama Mahasiswa, Kegiatan, Tingkat, Waktu Pelaksanaan, Hasil beserta tampil gambar Bukti Prestasi yang diupload oleh mahasiswa, selain itu terdapat tombol untuk kembali ke halaman sebelumnya.

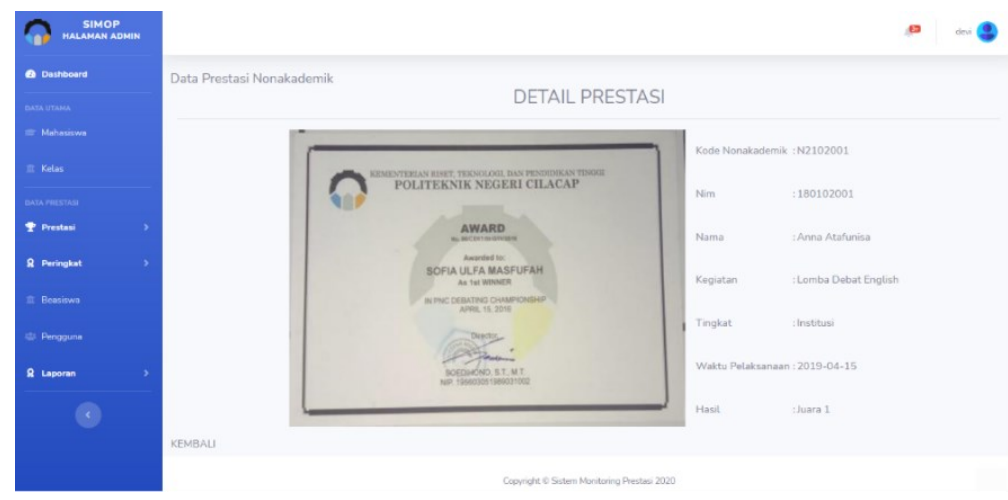

Gambar 7. Halaman Lihat Detail Non-akademik 
g. Halaman Lihat Data Kelas

Halaman melihat data kelas pada admin ini menampilkan data gridview yang berisi No, Kode Kelas dan Nama Kelas. Didalam data gridview, setiap data yang ada memiliki tombol Aksi yang terdiri dari tombol hapus yang berfungsi untuk menghapus data kelas dan tombol ubah yang digunakan untuk mengubah data kelas terpilih.

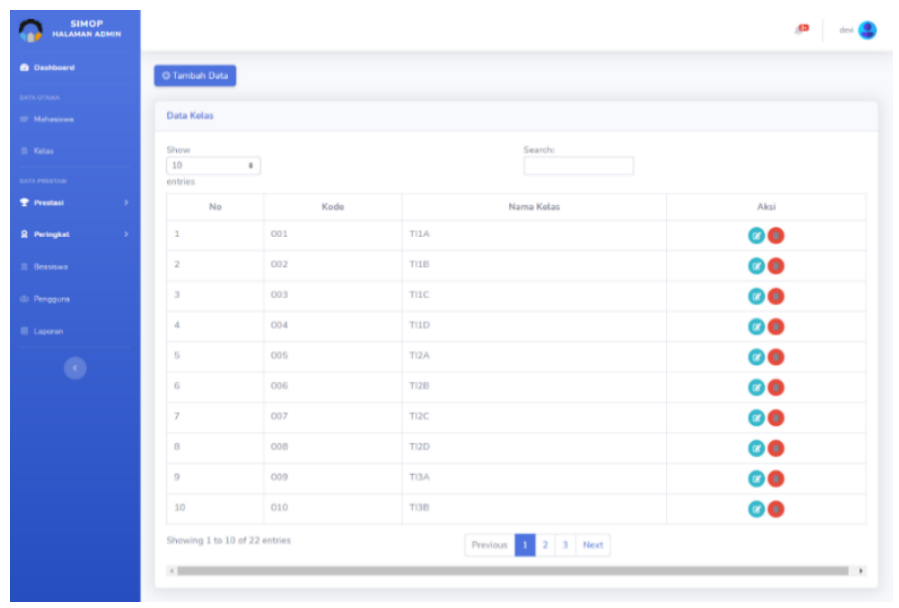

Gambar 8. Halaman Lihat Data Kelas

h. Halaman Lihat Data Beasiswa

Halaman melihat data beasiswa pada admin ini menampilkan data gridview yang berisi No, Kode Beasiswa dan Nama Beasiswa. Didalam data gridview, setiap data yang ada memiliki tombol Aksi yang terdiri dari tombol hapus yang berfungsi untuk menghapus data beasiswa dan tombol ubah yang digunakan untuk mengubah data beasiswa terpilih.

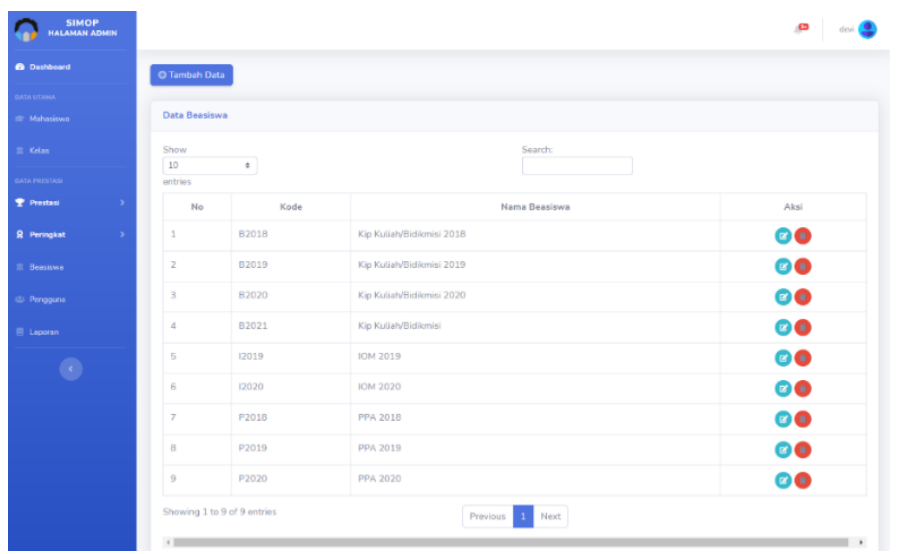

Gambar 9. Halaman Lihat Data Beasiswa

i. Halaman Lihat Grafik Nilai Akademik

Halaman lihat grafik akademik pada dashboard mahasiswa ini menampilkan data akademik yang berisi hasil pencapaian ipk per semester, setiap grafik yang muncul terdapat pilihan untuk mencetak atau menyimpan ke bentuk jpg atau png. 


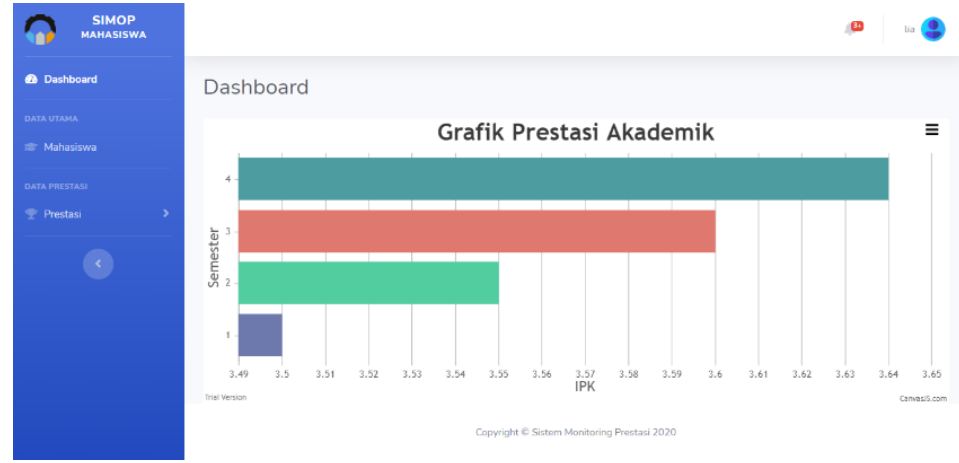

Gambar 10. Halaman Lihat Grafik Nilai Akademik

j. Halaman Lihat Lihat Peringkat akademik

Halaman melihat peringkat akademik pada admin ini menampilkan data gridview yang berisi No, Kode, Nim, Nama Mahasiswa, Semester, IPS dan IPK. Didalam data gridview ini data sudah terurut dari mahasiswa dengan nilai akademik terbesar hingga terkecil, setiap data yang ada memiliki tombol Aksi cari yang berfungsi untuk menampilkan grafik akademik yang terpilih.

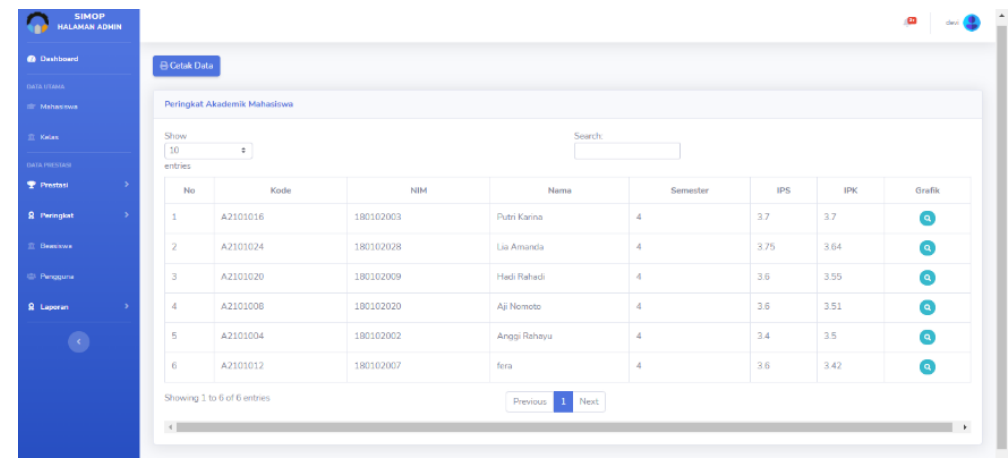

Gambar 11. Halaman Lihat Peringkat Akademik

k. Halaman Cetak Laporan Peringkat

Halaman cetak laporan rekapan peringkat akademik untuk Admin dan Anggota BAAK dapat mencetak data dengan menekan tombol cetak. Kemudian setelah selesai klik tombol cetak maka data siap untuk di cetak.

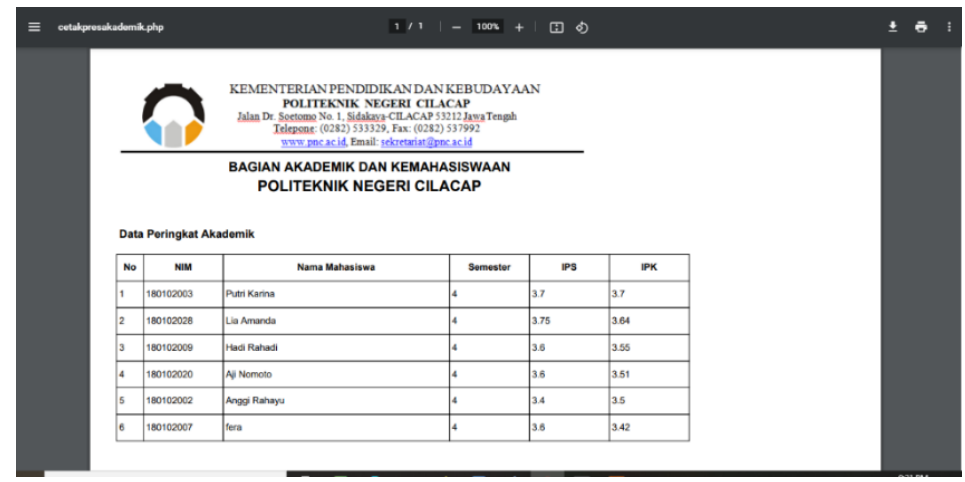

Gambar 12. Halaman Cetak Laporan Peringkat

1. Halaman Cetak Laporan Prestasi

Halaman cetak laporan prestasi untuk Admin dapat mencetak data dengan memilih jenis prestasi yang diinginkan yaitu nonakademik, organisasi, kepanitiaan dan karya ilmiah. Kemudian setelah selesai klik tombol cetak maka data siap untuk di cetak. 


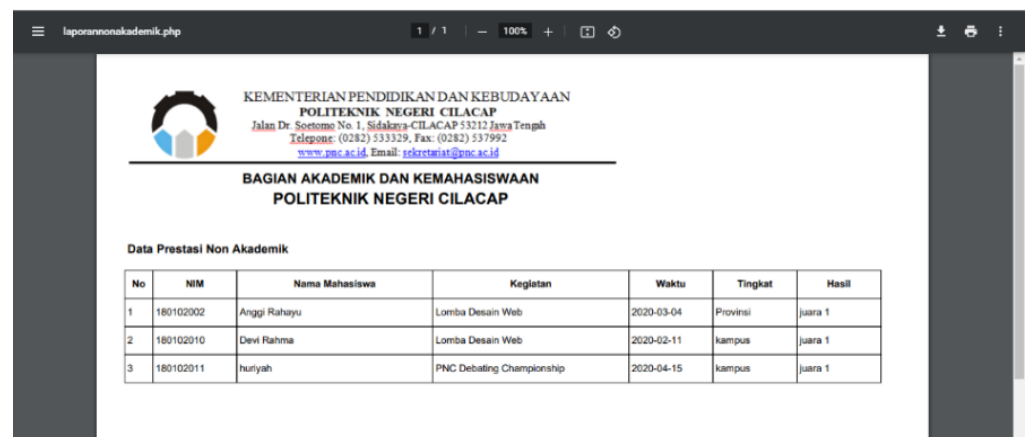

Gambar 13. Halaman Cetak Laporan Prestasi

\section{Pembahasan kuisioner}

Hasil analisis kuisioner Penerapan Metode Waterfall Pada Perancangan Sistem Informasi Monitoring Prestasi Mahasiswa yang terdiri dari lima pertanyaan berdasarkan uji responden yang telah dilakukan maka didapatkan jawaban dari 10 responden.

1) Sistem Mempermudah Admin Dalam Pengelolaan Dan Monitoring Data Prestasi Mahasiswa Untuk proses mempermudah pengelolaan data-data dan monitoring prestasi mahasiswa didapatkan hasil yakni 6 dari 10 responden (60\%) menyatakan baik, 3 dari 10 responden (30\%) menyatakan sangat baik, dan 1 dari 10 responden menyatakan cukup (10\%). Berikut tabel dan grafik hasil kuisioner:

Tabel 1. Sistem Mempermudah Dalam Pengelolaan Dan Monitoring Data Prestasi Mahasiswa

\begin{tabular}{c|c|c|c|c}
\hline \multicolumn{1}{c|}{ Keterangan } & $\begin{array}{c}\text { Sangat } \\
\text { Kurang }\end{array}$ & Kurang & $\begin{array}{c}\text { Cukup } \\
\text { Baik }\end{array}$ & $\begin{array}{r}\text { Sangat } \\
\text { Baik }\end{array}$ \\
\hline $\begin{array}{l}\text { Mempermudah admin dalam pengelolaan dan monitoring } \\
\text { data prestasi mahasiswa }\end{array}$ & - & -1 & 6 & \\
\hline
\end{tabular}

2) Sistem Mempermudah Pengguna Dalam Mengakses Informasi Terkait Prestasi Akademik Dan Nonakademik Yang Diperoleh Mahasiswa

Untuk proses mempermudah mengakses informasi terkait prestasi yang diperoleh mahasiswa didapatkan hasil yakni 3 dari 10 responden (30\%) menyatakan sangat baik serta 7 dari 10 responden $(70 \%)$ menyatakan baik. Berikut tabel dan grafik hasil kuisioner:

Tabel 2. Sistem Mempermudah Pengguna Dalam Mengakses Informasi Terkait Prestasi Akademik Dan Nonakademik Mahasiswa

\begin{tabular}{c|c|c|c|c}
\hline Keterangan & $\begin{array}{c}\text { Sangat } \\
\text { Kurang }\end{array}$ & Kurang & $\begin{array}{c}\text { Cukup } \\
\text { Baik }\end{array}$ & $\begin{array}{c}\text { Sangat } \\
\text { Baik }\end{array}$ \\
\hline $\begin{array}{l}\text { Mempermudah pengguna dalam mengakses informasi } \\
\text { terkait prestasi akademik dan nonakademik mahasiswa }\end{array}$ & - & - & -3 & \\
\hline
\end{tabular}

3) Sistem Mempercepat Proses Pemberitahuan Bagi Mahasiswa Penerima Beasiswa Bidikmisi Yang Mempunyai Ipk Rendah

Untuk proses mempercepat pemberitahuan bagi mahasiswa penerima beasiswa bidikmisi yang mempunyai ipk rendah didapatatkan hasil yakni 4 dari 10 responden (40\%) menyatakan sangat baik, 5 
dari 10 responden $(50 \%)$ menyatakan baik serta 1 dari 10 responden menyatakan cukup (10\%). Berikut tabel dan grafik hasil kuisioner:

Tabel 3. Sistem Mempercepat Proses Pemberitahuan Bagi Mahasiswa Bidikmisi IPK Rendah

\begin{tabular}{c|c|c|c|c|c}
\hline \multicolumn{1}{c|}{ Keterangan } & $\begin{array}{c}\text { Sangat } \\
\text { Kurang }\end{array}$ & Kurang & Cukup & Baik & $\begin{array}{c}\text { Sangat } \\
\text { Baik }\end{array}$ \\
\hline $\begin{array}{l}\text { Mempercepat proses pemberitahuan bagi mahasiswa } \\
\text { bidikmisi yang mempunyai ipk rendah }\end{array}$ & - & - & 1 & 5 & 4 \\
\hline
\end{tabular}

4) Kemudahan Pengoperasian Sistem

Untuk proses kemudahan dalam pengoperasian sistem didapatkan hasil yakni 3 dari 10 responden (30\%) menyatakan sangat baik, 5 dari 10 responden (50\%) menyatakan baik serta 2 dari 10 responden menyatakan cukup (20\%). Berikut tabel dan grafik hasil kuisioner:

Tabel 4. Sistem Mudah Dioperasikan

\begin{tabular}{c|c|c|c|c|c}
\hline Keterangan & Sangat Kurang & Kurang & Cukup & Baik & Sangat Baik \\
\hline Sistem mudah untuk dioperasikan & - & - & 2 & 5 & 3 \\
\hline
\end{tabular}

5) Tampilan Sistem Ramah Bagi Pengguna

Untuk tampilan antarmuka sistem ramah bagi pengguna didapatkan hasil yakni 6 dari 10 responden (60\%) menyatakan baik, 2 dari 10 responden (20\%) menyatakan sangat baik serta 2 dari 10 responden menyatakan cukup (20\%). Berikut tabel dan grafik hasil kuisioner:

Tabel 5. Tampilan Sistem Ramah Bagi Pengguna

\begin{tabular}{c|c|c|c|c|c}
\hline Keterangan & Sangat Kurang & Kurang & Cukup & Baik & Sangat Baik \\
\hline Tampilan antarmuka sistem ramah bagi pengguna & - & - & 2 & 6 & 2 \\
\hline
\end{tabular}

\section{Kesimpulan}

Berdasarkan hasil penelitian yang sudah dilakukan, dapat diambil beberapa kesimpulan "Penerapan Model Waterfall Pada Perancangan Sistem Informasi Monitoing Prestasi Mahasiswa" dapat membantu dalam pengelolaan data prestasi akademik, proses pengumpulan hasil prestasi nonakademik oleh mahasiswa kepada BAAK, penyampaian informasi perangkingan mahasiswa, penyampaian informasi grafik ipk, penyampaian informasi mahasiswa penerima beasiswa dan laporan rekapan hasil prestasi mahasiswa. Sehingga admin yang kesulitan dalam mengelola data prestasi akademik dan nonakademik akan terbantu dengan adanya Sistem Informasi Monitoring Prestasi Mahasiswa. Mahasiswa juga dapat mendapat informasi akademik melalui sistem tersebut. Sedangkan bagi anggota BAAK dapat mengetahui data-data akademik dan nonakademik secara cepat melalui sistem. Berasarkan hasil pengujian menggunakan blackbox testing, sistem telah mampu menangani permasalahan yang ada pada BAAK Politeknik Negeri Cilacap . Dari hasil analisa data kuisioner dengan 10 responden didapatkan bahwa 8,6\% menyatakan cukup, 55,5\% menyatakan baik dan 35,9\% menyatakan sangat baik. Untuk penelitian selanjutnya diharapkan dapat meningkatkan sistem lebih baik dengan menggunakan notifikasi ketika mahasiswa mengumpulkan prestasi sehingga lebih optimal. 


\section{Daftar Pustaka}

[1] J. Stmik, A. Riau, P. Km, I. Email, R. A. Development, and T. Rad, "Sistem Layanan Informasi Lapor Prestasi Mahasiswa STMIK Amik Riau,” J. INVOTEK Polbeng - Seri Inform., vol. 4, no.1, pp. 111-120, 2019.

[2] E. Sutinah, G. N. Azima, and E. F. Imaduddin, "Sistem Informasi Monitoring Akademik Dan Prestasi Siswa Dengan Metode Waterfall," J. Inf. Eng. Educ. Technol., vol. 2, no. 1, p. 47, 2018, doi: 10.26740/jieet.v2n1.p47-59.

[3] S. Suaidah, "Perancangan Monitoring Prestasi Akademik Dan Aktivitas Siswa Menggunakan Pendekatan Key Performance Indicator (Studi Kasus Sma N 1 Kalirejo),” J. Tekno Kompak, vol. 12, no. 2, p. 62, 2018, doi: 10.33365/jtk.v12i2.154.

[4] E. Y. Anggraeni and R. Irviani, Pengantar Sistem Informasi. Yogyakarta: CV. Andi Offset, 2017.

[5] J. P. Jumri, "Perancangan Sistem Monitoring Konsultasi Bimbingan Akademik Mahasiswa dengan Notifikasi Realtime Berbasis SMS Gateway," J. Sist. dan Teknol. Inf., vol. 1, no. 1, pp. 21-25, 2015.

[6] P. Sosial, D. I. Lingkungan, and S. Dan, "Studi Tentang Hubungan Dukungan Sosial, Penyesuaian Sosial Di Lingkungan Sekolah Dan Prestasi Akademik Siswa Smpit Assyfa Boarding School Subang Jawa Barat,” J. Psikol., vol. 10, no. 2, pp. 103-114, 2011, doi: 10.14710/jpu.10.2.103-114.

[7] J. Simarmata, Rekayasa Web, 1st ed. Yogyakarta: C.V ANDI OFFSET, 2010.

[8] J. Simarmata, Rekayasa Perangkat Lunak. Yogyakarta: C.V ANDI OFFSET, 2010.

[9] bin A. Ladjamudin, Analisis dan Desain Sistem Informasi. Yogyakarta: Graha Ilmu, 2013.

[10] M. Rais, "Penerapan Konsep Object Oriented Programming Untuk Aplikasi Pembuat Surat," J. PROtek, vol. 6, no.2, pp. 96-101, 2019.

[11] A. Tri Laksono, D. Novia Prasetyanti, and A. Agung Hartono, "Sistem Informasi Akademik Berbasis Web pada Lembaga Bimbingan Belajar," J. Innov. Inf. Technol. Appl., vol. 2, no.2, pp. 152-158, 2020, doi: doi.org/10.35970/jinita.v2i2.402.

[12] I. Sommerville, Software Engineering 9th Edition (Rekayasa Perangkat Lunak). Jakarta: Erlangga, 2011.

[13] Hendri, J. W. Hasiholan Manurung, R. Audi Ferian, W. Hanaatmooko Faharrudin, and Y. Yulianti, "Pengujian Black Box Pada Aplikasi Sistem Informasi Pengelolaan Masjid menggunakan Equivalence Partition," J. Teknol. Sist. Inf. dan Apl., vol. 3, no.2, p. 7, 2020, doi: 10.32493/jtsi.v3i2.4694.

[14] S. Ikhlaashi and H. Prihantoro Putro, "Komparasi Dua Teknik Black Box Testing: Equivalence Partitioning dan Boundary Value Analysis,” Annu. Res. Semin., vol. 5, no. 1, p. 8, 2019.

[15] Debiyanti, Sutrisna, Budrio, A. Kurnia Kamal, and Yulianti, "Pengujian Black Box pada Perangkat Lunak Sistem Penilaian Mahasiswa Menggunakan Teknik Boundary Value Analysis," J. Inform. Univ. Pamulang, vol. 5, no.2, p. 5, 2020, doi: 10.32493/informatika.v5i2.5446. 